\title{
EMPIRICAL INVESTIGATION OF THE UNDERPRICING PHENOMENON ON IPOS IN PRIVATIZATION OF SOEs: EVIDENCE FROM INDONESIA
}

\author{
Monika Setiobudi ${ }^{1}$ \\ BINUS University International, Jakarta \\ Dezie L. Warganegara ${ }^{2}$ \\ BINUS University International, Jakarta \\ Doni S. Warganegara ${ }^{3}$ \\ Universitas Lampung
}

\begin{abstract}
The Objective this empirical research is conducted with the main purpose to assess whether the short-run underpricing level of IPOs on privatization is lower or not compared to the privately owned enterprises in Indonesia. The aim is intended to identify whether the presence of excessive underpricing is occurred among the Privatization IPOs in Indonesia.

Method are used to fullfil the objective, the samples are derived from both SOEs and Non-SOEs that conducted the Initial Public Offerings (IPO) during period 2000-2009. The total final samples used are 147 samples. Moreover, this research focuses on the initial return of the first trading day to determine the underpricing level. The data is also analyzed by using descriptive statistics, Kolmogorov Smirnov test, parametric tests, Nonparametric tests and Multiple Regression Analysis.

Result of the research shows the evidence that the extent of underpricing is significantly lower in IPOs conducted by the SOEs compared to the privately owned in Indonesia. Furthermore, the result also clarifies that there is no occurrence of excessive underpricing within the Privatization IPOs in Indonesia.

Conclusion is the degree of underpricing within the SOEs is proven to be lower than the Non-SOEs. This fact is supported by the reasons of tight

\footnotetext{
${ }^{1}$ Alumni of BINUS University International, monika_setiobudi@hotmail.com

${ }^{2}$ Faculty of Business, School of Accounting \& Finance - BINUS University International

${ }^{3}$ Faculty of Economics, School of Accounting - Universitas Lampung
} 
standardize legislation, underwriter's reputation, budget deficit in Indonesia, and well-established industry within the SOEs.

Keywords: Privatization, Underpricing, Initial Public Offering (IPO), State-Owned Enterprises (SOE), and Initial Return.

\section{INTRODUCTION}

Existence of IPO around the world within the business community was mainly dominated by privately owned enterprises. However, as the time goes by, this state has caught the attention of state-owned enterprises (SOEs) to also engage with go public issues In Indonesia itself, there were several evidences associated with privatized SOEs. However, a comprehensive privatization program of SOEs was clearly commenced in the aftermath of the Asian Financial Crisis. Correspondingly, Irianto (2004) mentioned that crisis and international pressure, budget deficit as well as poor SOEs performance have primarily driven the government in doing the privatizations to deal with the severe crisis.

Regardless the terms of carrying out IPOs, there is usually an anomaly trend that is most likely to happen, known as the underpricing phenomenon. Numerous literatures and research also have been showing that the average of initial public offering (IPOs) are inclined to be underpriced (Alexakis, 2007). He also added that short run underpricing phenomenon occurred at the end of first day of trading as the difference between offering price of a stock and its market price. It is also known as first day return or initial return. According to Loughran, Ritter and Rydqvist (1994), all 25 countries with accessible statistical data are encountered underpricing in the short run. The underpricing itself is mainly observed using one-day initial return but some exceptions where price movements are restricted or trading does not commence promptly, period of weeks or months elapses between the offering day and the market price is used.

Furthermore, the underpricing phenomenon is not only occurred around privately-owned enterprises but it also taken place within the privatization form. An auxiliary proposition has arisen on this implication of 
underpricing, as various objectives have exceeded the primary advantage on the sales price of the current IPO and drive some government to more likely underprice its privatization offerings. The latest issue on underpriced privatization IPOs has even emerged in Indonesia during early November 2010. The information given by Megawati (2010), involved Krakatau Steel as the largest integrated steel producer in Southeast Asia. This underpricing case is still under investigation of Indonesia's House of Representatives due to the possibility of irregularities conspiracy in cheap shares pricing at 850 rupiah $(\$ 0.09)$ per share during the IPO.

Seeing that the extent of IPO has been covering both privately and stateowned enterprises, thus many possibilities have arisen from the action that has been made by these major participants of the IPOs. One of the significant question marks that left behind within business society is correlated with the underpricing phenomenon, particularly in terms of privatization forms. Numerous researchers around the world have come out with various results on underpricing. However, all of them agree that this matter is remained as a hot issue and require further exploration throughout these days. Thus, this research is committed to evaluate whether underpricing level of IPOs on privatization is less significant or not compared to the one on privately owned enterprises in Indonesia. The author would therefore entitle this research as: "Empirical Investigation of the Underpricing Phenomenon on IPOs in Privatization of SOEs: Evidence from Indonesia”

\section{THEORITICAL FOUNDATION}

The pricing valuation of initial public offerings (IPOs) is facing a great deal of difficulties ever since there is no observable market price prior to the offering made by the company. Ibbotson (1975), as the early writer of this phenomenon also has discovered that share price of a going public company will jump substantially and tend to be underpriced on the first day of trading. Numerous literatures and research also have been showing that the average of initial public offering (IPOs) are inclined to be underpriced (Alexakis, 2007). He also added details similar to Ibbotson's findings that short run underpricing phenomenon occurred at the end of the first day of trading as the difference between offering price of a stock 
and its market price. Ernyan and Husnan (2002) and Desyetti and Adriyanto (2004) found the significant result on positive initial return that conveyed underpricing in Indonesian Capital market.

Moreover, Underpricing theories are generally derived from asymmetric information model, in which considering that one party acquires further information than the others. However, many researchers found several other driven factors aside from this model in relation with underpricing performance, such as winner's curse hypothesis, signaling theory and principal agent theory.However, occurrence of underpricing phenomenon is not only around privately-owned enterprises but also taken place within the privatization form. Various researchers such as, Huang and Levich, (1999), Choi and Nam (1998), Dewenter and Malatesta (1997) and Ljungqvist, Jenkinson and Wilhelm (2000) have examined worldwide underpricing phenomenon by comparing these two groups.

In additon, Privatization IPOs (PIPOs) should have encountered less business risk and result on less underpricing than private sectors based on the traditional theory of asymmetry information which was employed by Choi and Nam (1998) and Dewenter and Malatesta (1997). This interpretation was also emerged and supported based on the fact that stateowned enterprises usually run in large scale and well established industry with a long track record compared to new or less-known companies in private IPOs. The literatures made by Carter, Dark, \& Singh (1998) and Ritter, $(1984,1991)$ also exposed that more established firms are bearing less threat within the company. Specifically, SOE is often connected with how long the company has been operating and continue to exist to become the proficient one in its industry, by maximizing the chance in competitive business opportunities that exist in the economy. Moreover, this research also in line with the study conducted by Carter, Dark, \& Singh (1998), Dunbar, (2000), and Jain \& Kini, (2000) that the more established firms would normally offer larger IPOs and reduces perceived risk of the offering price. Beatty and Ritter (1986) also procured that smaller offering on average is more speculative with greater uncertainty corresponding to larger parts.

The legal proponent of SOEs itself holds ministerial position and supported by members of the House of Representatives through the 
legislation issuance (Law of SOEs No. 19/2003) on June 19, 2003. Moreover, the standardize legislation associated with the action of Privatization SOEs is also ratified in the Government Decree No. 33/2005, in which contained the regulation of all privatized SOEs should be competitive in its industry (Chapter 3, article 7 of Government Decree No. 33/2005). In addition, Prominence SOE is able to diminish the intervention of underwriter reputation, as the government enterprise does not seek any advantages from it to ensure the quality of the shares and reduce the uncertainty level of the shares during privatization occurrences (Government Decree no 33/2005 on Chapter 4, part 3, article 13-17). The legal regulations also emphasize on the government selection over the appropriate underwriter.The cost of privatization itself must serve principles of fairness, transparency and accountability, which is set by the Minister of SOE (Chapter 4, part 4, article 19 of Government Decree No. $33 / 2005)$. Hence, government as major shareholder will provide better guarantees for investors and eliminate the uncertainty about the real value of the shares. However, this standard itself did not rule the probability occurrence of asymmetric information to induce underpricing level in privatized enterprises in Indonesia.

\section{HYPOTHESIS DEVELOPMENT}

This research will develop the model to examine the initial returns earned by investors on the initial public offering within two separated groups of the listed companies. It comprises the existence of underpricing phenomenon in Indonesian Stock Exchange for both privately owned and state-owned groups of enterprises. Prior studies around the world have been done to determine the occurrence of underpricing phenomenon through findings from Ibbotson (1975), Ritter (1984), Ibbotson, Sindelar and Ritter (1988), Loughran, Ritter and Rydqvist (1994) and Alexakis (2007). Their documentation found that the share price of a going public company will jump substantially and tend to be underpriced on the first day of trading. This phenomenon conformed by Beatty (1989) as a realistic transfer of wealth from issuer to the investors, thus the issuers are necessary to be cautious in underpricing their offering price.

Different goals and objectives to benefit oneself from each party involved in this going public process promotes every individual to equally take part 
in contriving the underpricing phenomenon. Furthermore, asymmetric information in this situation has aggravated this situation even worse. Various capital markets around the world are encountered underpricing problems that originated from asymmetry of information as the root of this complicated issue and arrive with the implication on issuers, underwriters, as well as investors as the related parties. Loughran, Ritter and Rydqvist (1994) draw a conclusion from all 25 worldwide countries with the accessible statistical data are encountered underpricing in the short run. In Indonesia itself, Ernyan and Husnan (2002) and Desyetti and Adriyanto (2004) found the significant result on positive initial return that conveyed underpricing in Indonesian Capital Market.

In evaluation, underlying theory of higher average of initial returns is due to the uncertainty of the value of the firm, winner's curse condition and principal-agent cost. This theory is mostly related to asymmetric information between related parties, which develop into other relevant issues such as principal-agency cost and the attempt of signaling. The motive of underpricing on the first place is based on the compensation given by issuer on the uncertainty about the value of the offered shares to the investors. In addition, this is also accordance with signaling theory based on Allen and Faulhaber (1989), Grinblatt and Huang (1989) and Welch (1989) as useful tool in directly give signal to the potential investors. As the firm itself conquers better information of its future prospect, only IPOs from good firms can send high-quality signal to investors.

Further aspect is involving investment banker as underwriter, which is trying to suppress pricing of shares in order to sell all the shares, ever since they must buy back the shares if the shares are not sold out (Baron, 1982). The other substantial reason is also to build a good for reputation by sold out or even oversubscribe and provide abnormal returns to investors (Beatty and Ritter, 1986). Lastly, the underlying reason is due to the issuers must continue to catch the attention of uninformed as well as informed investors to avoid massive adverse selection (Rock, 1986). Thus, new issues must be on average underpriced to provide uninformed investors with appropriate rates of return and attract more participation from them. 
Despite the causes of underpricing itself, the occurrence of underpricing phenomenon is not only around privately-owned enterprises but it also taken place within the privatization form. Various researchers such as, Huang and Levich (1999), Choi and Nam (1998), Dewenter and Malatesta (1997), and Ljungqvist Jenkinson and Wilhelm, (2000) have examined the insight of worldwide underpricing phenomenon by comparing these two groups. An auxiliary proposition has arisen on this implication of underpricing as various objectives have exceeded the primary advantage on the sales price of the current IPO and drive some government to more likely underprice its privatization offerings. This proposition is trying to discern the significance level of underpricing within the privatization and privately owned enterprises. This phenomenon was dominantly support with asymmetric information theory. It generally describes that IPO underpricing is positively related to uncertainty level on the value of the assets.

However, Privatization IPOs (PIPOs) should have encountered less business risk and result on less underpricing than private sectors based on the traditional theory of asymmetry information which was employed by Choi and Nam (1998), Carter, Dark, \& Singh (1998), Ritter (1984,1991) and Dewenter and Malatesta (1997). This interpretation was also emerged and supported based on the fact that state-owned enterprises usually run in large scale and well established industry with a long track record compared to new or less-known companies in private IPOs. The interconnection between underpricing and privatization can also be noticed in Indonesian state-owned enterprises. The preparation of privatization program has been set through the ministry of state owned enterprises or state owned enterprises agency. Moreover, this research also in line with the study conducted by Carter, Dark, \& Singh (1998), Dunbar (2000), and Jain \& Kini, (2000) that the more established firms would normally offer larger IPOs and reduces perceived risk of the offering price. Beatty and Ritter (1986) also procured that smaller offering on average is more speculative with greater uncertainty corresponding to larger parts.

Moreover, the standardize legislation of the action of Privatization SOEs is ratified in the Government Decree No. 33/2005 and preserve a tight atmosphere in the privatization process, such as all privatized SOEs 
should be competitive in its industry, which mostly the market leader in its industry (Chapter 3, article 7 of Government Decree No. 33/2005) and the cost associated with privatization itself must serve the principles of fairness, transparency and accountability (Chapter 4, part 4, article 19 of Government Decree No. 33/2005).

Moreover, Prominence status of state-owned enterprise is able to diminish the intervention of underwriter reputation as the government enterprise does not seek any advantage from the underwriter reputation to ensure the quality of the shares and reduce the uncertainty level of the shares. In addition, the legal regulation of Government Decree No. 33 /2005 on Chapter 4, part 3, and article 13-17 also has set certain specification to determine the most suitable underwriter to carry out the IPO process and the government will have a direct supervision on the performance of the underwriter. Thus, the underwriter must also provide the best appraisal for the go public SOE to determine the general underpricing level. Hence, the government as major shareholder will provide better guarantees for investors and eliminate the uncertainty about the real value of the shares. Consequently, the hypothesis will be established as follows:

Hypothesis 1:

$\mathrm{H}_{\mathrm{A} 1}$ : The initial mean return of privatization of IPOs in Indonesia is less compared to the return in private sector IPOs.

\section{DATA AND RESEARCH METHODOLOGY}

\section{Samples Data}

The author uses purposive sampling methods to obtain samples. The total population of this study is 425 public listed companies in Indonesian Stock Exchange throughout 2011. The author has come to a decision to limit the samples of data into 162 newly listed companies from the period 2000-2009, which comprises both privately and state owned enterprises. However, those IPO companies have to meet several requirements to be categorized in the final samples, as follows:

1. Have a complete set of financial data required to estimate Initial return at first trading day, Total Assets, OROA, Leverage, Retained Ownership and Total Gross Proceed. Hence, 10 
companies were further eliminated since they do not provide complete accessible data to be extracted in this research.

2. Provide relevant prospectus prior to its IPO process. Thus, 5 IPO companies are eliminated due to unavailability of the prospectus provided in Indonesian Stock Exchange.

As a result those companies will have to be omitted from the research sample and leave 147 IPO companies as the final samples.

\section{Data Methodology}

The research presents the result of one sample t-test and the binomial test to confirm the occurrence of underpricing level throughout the entire IPO companies in Indonesia. Furthermore, this research will also conduct the individual test for both groups related with the extent of undepricing. Hence, the result observed will be focusing on each group to determine the existence of underpricing. The result of one sample t-test and the binomial test will confirm the occurrence of underpricing level for each of the IPO performed by SOE and Non- SOEs Additionally, the main exploration in this study is to investigate the difference of underpricing level among the SOEs and Non-SOEs. The hypothesis is to investigate on whether the underpricing level of SOEs subsample would be lower than the NonSOEs subsample. To test this possibility, the two subgroups will be analyzed by conducting the independent sample t-test and its nonparametric corresponding item, the Mann-Whitney $U$ test. The approach in this research is using one-tailed test due to the research hypothesis is determining on whether the underpricing level of SOEs subsample would be lower than the Non- SOEs one, which focus simply on one side

Moreover, this research also conduct multiple regression analysis which is based on the underpricing level as the dependent variable and affected by the main dummy variable which defines the IPOs of privatization with 1 and 0 for otherwise. There are also control variables including, Age, Gross Proceeds, OROA, Retained Ownership, and Leverage. Research model given below is to test the first hypothesis determined earlier by means of purpose to find the correlation between the degree of underpricing and all related independent variables on all IPOs that went public from 2000 to 2009. The author would examine the firm year observation of underpricing level for both state-owned and privately owned enterprises 
listed in the IDX using the multiple regression equation. In addition, the result from adjusted R-square would facilitate in gaining better insight about the model.

Model:

$$
\begin{aligned}
\text { Underpricing }_{i t} & =\beta+\beta_{1}\left(D U_{-} S O E\right)_{i t}+\beta_{2}(\text { Age })_{i t} \\
& +\beta_{3}(\text { Proceeds })_{i t}+\beta_{4}(\text { OROA })_{i t}+\beta_{5}(\text { Retown })_{i t} \\
& +\beta_{6}(\text { Leverage })_{i t}+\varepsilon_{i t}
\end{aligned}
$$

Given:

Underpricing $_{\text {it }}=$ Undepricing returns of the IPO firm $\mathrm{i}$ that went public at year $\mathrm{t}$.

$\beta_{1}$ DU_SOE $_{\text {it }} \quad=$ Dummy variables which equal to the value of 1 if the IPOs are from state-owned enterprises (privatization) and 0 if otherwise.

$\beta_{2}$ Age $_{\text {it }} \quad=$ Company age of firm $\mathrm{i}$ at year $\mathrm{t}$.

$\beta_{3}$ Gross Proceeds ${ }_{i t}=$ Number of the offering shares multiplies by the offering price of company $i$ at year $t$.

$\beta_{4} \mathrm{OROA}_{\text {it }} \quad=$ Operating returns on assets of company $\mathrm{i}$ at year $\mathrm{t}$.

$\beta_{5}$ RetOwn $_{\text {it }} \quad=$ Percentage of shares owned by the SOEs and non SOEs at the year of issuing.

$\beta_{6}$ Leverage $_{\text {it }} \quad=$ Debt ratio of company $\mathrm{i}$ at year $\mathrm{t}$.

$\varepsilon_{\text {it }} \quad=$ Error Term 


\section{FINDINGS AND DISCUSSION}

The research presents the result of one sample t-test and the binomial test to confirm the occurrence of underpricing level throughout the entire IPO companies in Indonesia.

Table 1. Test for the Extent of Underpricing from Total Samples

\begin{tabular}{lr}
\hline N = 147 IPO firms & $\begin{array}{r}\text { Initial Return } \\
\text { (IR) }\end{array}$ \\
\hline Mean & 0.440646143 \\
Median & 0.225045 \\
Standard Deviation & 0.798978024 \\
One sample t-statistics & 6.687 \\
p-value for one tailed t-test & 0.000 \\
p-value for one tailed Binomial test & 0.000
\end{tabular}

Furthermore, the result from binomial test is proven to be strongly significant as the p-value result is less than $1 \%$ significant level. In addition, the result for one sample t-test also has the p-value less than $1 \%$ significant level. Thus, there is an indication that IPOs performed by both SOEs and Non-SOEs will experience underpricing at the first trading day. The result is now valid as the general information since it has proven through the statistical tests.

Furthermore, this research will also conduct the individual test for both groups related with the extent of undepricing. Hence, the result observed will be focusing on each group to determine the existence of underpricing. 
Table 2. Individual Test for Underpricing of SOE and Non-SOE

\begin{tabular}{llr}
\hline \multirow{2}{*}{$=147$ IPO firms } & \multicolumn{2}{c}{ Initial Return (IR) } \\
\cline { 2 - 3 } & \multicolumn{1}{c}{ SOE } & $\begin{array}{r}\text { Non- } \\
\text { SOE }\end{array}$ \\
\hline Mean & 0.050195321 & 0.469146 \\
Median & 0.125 & 0.26087 \\
$\begin{array}{l}\text { Standard Deviation } \\
\text { t-statistics }\end{array}$ & 0.32190939 & 0.816345 \\
$\begin{array}{l}\text { p-value for one tailed t-test } \\
\text { p-value for one tailed Binomial } \\
\text { test }\end{array}$ & 0.493093852 & 6.726587 \\
& 0.316876739 & 0.0000 \\
& 0.0546875 & 0.0000
\end{tabular}

Table 2 in the above presents the result of one sample t-test and the binomial test to confirm the occurrence of underpricing level for each of the IPO performed by SOE and Non- SOEs. The p-value of SOE by using binomial test is significant under the $10 \%$ significant level with the value of $5.46 \%$. Additionally, the p-value result of Non-SOE by using the same method has also produced the p-value of lower than 1\% significant level. Thus, the result of the p-value for Non-SOE is in conformity with the result for SOE and depicted the presence of underpricing in both groups. In conclusion, individual tests for both groups are supporting the notion that there is underpricing phenomenon among those two groups, as the research will rely more on the result of non-parametric test rather than the parametric test.

Additionally, the main exploration in this study is to investigate the difference of underpricing level among the SOEs and Non-SOEs. The hypothesis is to investigate on whether the underpricing level of SOEs subsample would be lower than the Non- SOEs subsample. 
Table 3. Comparison Test for Underpricing level between SOE and NonSOE

\begin{tabular}{llr}
\hline N = 147 IPO firms & \multicolumn{2}{c}{ Initial Return (IR) } \\
\hline Mean & 0.050195321 & 0.469146 \\
Median & 0.125 & 0.26087 \\
Standard Deviation & 0.32190939 & 0.816345 \\
2-independent sample t-statistics & \multicolumn{2}{c}{-1.6090} \\
(1 tailed p-value) & \multicolumn{3}{c}{0.055} \\
Mann-Whitney U statistics & \multicolumn{3}{c}{-1.820} & \\
(1 tailed p-value) & \multicolumn{3}{c}{0.0345} &
\end{tabular}

Furthermore, the first test was assessed by using the Mann-Whitney U test and produces the p-value of $3.45 \%$, which is less than $5 \%$ significant level. Thus, the null hypothesis can be rejected as the result is significant to validate the alternative hypothesis. In addition, the result is also strengthened by the result of the parametric test which also has the p-value lower than the conventional levels with the value of $5.5 \%$. Although the parametric test is only an ancillary test for this research, however the result produced is still in line with the result from Mann-Whitey $\mathrm{U}$ test. Thus, the null hypothesis that the degree of underpricing on SOEs is not less than that of Non-SOEs can be rejected, as the p-value is lower than the conventional level. The statistical outcome has clearly reinforced the fact that the observed initial return on SOE is less underpriced than NonSOEs. The aforementioned result of this research has authenticated the evidence of less underpricing amidst in the SOEs. More importantly, the null hypothesis for both subsamples was rejected by using independent sample t-test and its nonparametric corresponding item, the MannWhitney U test.

These findings corresponded with findings from Athens exchange by Alexakis (2007) but opposed to Samarakoon (2010) and Ljungqvist, Jenkinson and Wilhelm (2000)'findings. The results from this study also provide response regarding the argument by Dewenter and Malatesta (1997) and Huang and Levich (1999) which cannot reveal any tendency that privatization is more underpriced than private sectors and they come up with inconclusive opinion. Thus, the findings will be supporting the 
prior research as underpricing in privatization was varies within counties. Therefore, the notion of higher underpricing within the IPO performed by the SOE in Indonesia is not supported by the data in Indonesia.

The Privatization IPOs (PIPOs) is believed to be encountered less business risk and result on less underpricing than private sectors based on the traditional theory of asymmetry information which was employed by Choi and Nam (1998) and Dewenter and Malatesta (1997). This interpretation was supported based on the fact that SOEs usually run in large scale and well established industry with a long track record compared to new or less-known companies in private IPOs. The literatures made by Carter, Dark, \& Singh (1998) and Ritter $(1984,1991)$ also elucidated that more established firms are bearing less threat within the company.

Moreover, this research also in line with the study conducted by Carter, Dark, \& Singh (1998), Dunbar (2000), and Jain \& Kini, (2000) that the more established firms would normally offer larger IPOs and reduces perceived risk of the offering price. Thus, the underpricing within the SOEs can be minimized ever since the social status of the company itself has diminished the asymmetric information that lies within. Additionally, the preparation of privatization program has been strictly set under the ministry of state owned enterprises agency in Indonesia at the first place. The legal proponent of SOEs itself holds ministerial position and supported by members of the House of Representatives through the legislation issuance (Law of SOEs No. 19/2003) on June 19, 2003.

Moreover, the standardize legislation associated with the action of Privatization SOEs is also ratified in the Government Decree No. 33/2005, in which contained the regulation of all privatized SOEs should be competitive in its industry (Chapter 3, article 7 of Government Decree No. 33/2005). Furthermore, the cost of privatization itself must serve principles of fairness, transparency and accountability, which is set by the Minister of SOE (Chapter 4, part4, article 19 of Government Decree No. $33 / 2005)$. Thus, the costs for conduct the IPO will not be exaggerate and build upon the appropriate estimation on government's budget.

However, the purpose of underwriter in privatization IPO is dissimilar with the purpose of the private issuers that will utilize reputable underwriter to ensures the quality of the offered shares and reduce the 
uncertainty level. The prominence state-owned enterprise is able to diminish the intervention of underwriter reputation, as government enterprise does not seek any advantage from the underwriter reputation. Thus, the purpose of underwriter within the privatization IPO is merely administers the public issuance and distribution of securities to the investors.

Moreover, the legal regulation also emphasizes and holds the control over the tight screening over the appropriate underwriter for the privatization occurrences (Chapter 4, part 3, article 13-17of Government Decree No. 33/2005). As a result, the chosen investment banker cannot manipulate and suppress pricing of the share in order to minimize the selling effort as well as diminish the probability to buy back all the unsold shares. Thus, the investment banker will have to deal with the most appropriate valuation on the shares offered to the public, result in lower underpricing compared to the private sectors.

The primary aim of privatization process itself is also influencing the degree of underpricing throughout the IPO. Primarily privatization in Indonesia was driven as to deal with the budget deficit build upon the findings from Irianto (2004). However, a comprehensive privatization program of SOEs was clearly commenced in the aftermath of the East Asian Financial Crisis. Nevertheless, the tendency of selling the government stake in the SOEs was pondered as a viable choice and likely considered as the coincident effort to pursue. Since that major crisis, Indonesia is still experiencing the budget deficit until now. Even though the deficit is not as severe as the prior era, but the existence of budget deficit is still haunting the Indonesian government. Thus, the government needs to finance the budget deficit by using the fund raised from the privatization of IPO and this underlying reason in some way will diminish the degree of underpricing on it. 
Table 4. Multiple Regression Analysis

\begin{tabular}{|c|c|c|c|c|c|}
\hline \multicolumn{6}{|c|}{ Dependent Variable : Initial return } \\
\hline $\begin{array}{l}\text { Independent } \\
\text { Variable }\end{array}$ & Coefficient & Std. Error & t-statistic & p-value & $\begin{array}{l}\text { Predicted } \\
\text { sign }\end{array}$ \\
\hline Constant & 4.17234 & 1.077166 & 3.873443 & 0.0002 & \\
\hline DSOE & -0.059891 & 0.129157 & -0.46371 & 0.6436 & $(-)$ \\
\hline Leverage & -0.024738 & 0.262491 & -0.09424 & 0.9251 & $(+)$ \\
\hline Age & -0.109844 & 0.093482 & -1.17503 & 0.242 & $(-)$ \\
\hline Gross Proceed & -0.121994 & 0.030384 & -4.01507 & 0.0001 & $(-)$ \\
\hline OROA & 0.251762 & 0.203018 & 1.240097 & 0.217 & $(-)$ \\
\hline RetOwn & -0.509435 & 0.504489 & -1.0098 & 0.3143 & $(-)$ \\
\hline R-squared & 0.100455 & & & & \\
\hline Adjusted R-squared & 0.061903 & & & & \\
\hline F-statistic & 2.605714 & & & & \\
\hline $\operatorname{Prob}($ F-statistic) & 0.020023 & & & & \\
\hline
\end{tabular}

$\mathrm{DSOE}=$ a dummy variable that takes the value of 1 if IPO company is classified as $\mathrm{SOE}$ and zero otherwise. Leverage $=\mathrm{a}$ control variable that represents the debt ratio of IPO company one year prior to IPO process. Age $=$ a control variable that represents the natural log from the total number of years between the company's date of incorporation and the date of their IPOs. Gross Proceed $=$ a control variable that represents the natural log of total amount acquired during the IPO. $\mathrm{OROA}=$ a control variable that represents by dividing a company's annual operating income with average total asset of last fiscal year prior to the IPO year and the second-to-last fiscal year prior to the IPO. Retained Ownership $=\mathrm{a}$ control variable that is represented by the portion of shares held by the company.

Multiple regressions is conducted to determine more comprehensive outcome about techniques for modeling and analyzing several variables, when the focus is on the relationship between a dependent variable and one or more independent variables. The magnitude of the relationship 
among the variables has the value of R-squared and adjusted R-squared for $10.04 \%$ and $6.19 \%$, respectively. Those values are categorized to be relatively weak for cross sectional analysis. The evaluation shows that quite various unexplainable dependent variable by the independent variable. It can be estimated that only $6.19 \%$ of dependent variable can be explained by the independent variables, and left $93.81 \%$ of it to be remained unexplainable due to the presence of omitted variables that are not used in this research.

The main independent variable as represent by the dummy variable of SOEs has the same actual direction of coefficient as the prior predicted sign, thus it should be halved and become $32.18 \%$. However, the p-value falls above the conventional level and shows that the independent variable is not significant to influence the first day initial return as the dependent variable. Therefore, the nature of the ownership has not shown that the go public SOEs is offering lower initial return compared to the Non-SOEs. This result shows that the underpricing among SOEs and Non-SOEs is similar one to another.The result of multiple regression analysis produces the outcome of main independent variable of dummy SOE to be insignificant to explain the extent of underpricing. The other control variables are utilized to obtain a comprehensive result from this reaearch. Therefore, the focus of this test is relying on the nature of SOE itself which correspond to the main dummy SOE. In the end, the nature of SOE does not exactly experience lower underpricing compared to the NonSOE. This shows that the result of underpricing among SOE and NonSOE to be similar one to another. This finding can be interpreted as the anomaly of underpricing is generally the same for both SOE and NonSOE within the business society in Indonesia within the last 10 years period. 


\section{CONCLUSION AND RECOMMENDATION}

\section{Conclusion}

Underpricing phenomenon has been one of the most complex anomalies during the process of go public process. Prior studies around the world have been done to determine the occurrence of underpricing phenomenon through findings from Ibbotson (1975), Ritter (1984), Ibbotson, Sindelar and Ritter (1988) and Loughran, Ritter and Rydqvist (1994) and Alexakis (2007) .Their documentations found that the share price of a going public company will jump substantially and tend to be underpriced on the first day of trading. This phenomenon conformed by Beatty (1989) as a realistic transfer of wealth from issuer to the investors, thus the issuers are necessary to be cautious in underpricing their offering price.

Seeing that the extent of IPO has been covering both privately and stateowned enterprises, thus many possibilities have arisen from the action that has been made by these major participants of the IPOs. One of the significant question marks that left behind within business society is correlated with underpricing phenomenon particularly in terms of privatization forms. Thus this research is committed to make some estimation on whether underpricing level of IPOs on privatization is less significant or not compared to the one on privately owned enterprises in Indonesia.

The main purpose of this study is to answer the research question. By the end of the research, the following answer to research question is discovered:

1. Does the underpricing extent in Indonesian listed companies is lower within the SOE compared to the Non-SOE?

The Indonesian companies that conducted IPO during the period of 2000 to 2009 found that the initial return of first trading day by the SOE is generally less underpriced than the private sectors based on univariate test that have been conducted. This action is made possible by the supportive evidence surrounds the atmosphere of SOE itself. Several facts and evidences are supporting the notion of less asymmetric information among the SOE.

Firstly, the Privatization IPOs (PIPOs) will encounter less business risk and result on less underpricing than private sectors as based on the traditional theory of asymmetry information which was employed by Choi 
and Nam (1998), Carter, Dark, \& Singh, (1998), Ritter (1984, 1991) and Dewenter and Malatesta (1997). This interpretation was supported based on the fact that state-owned enterprises usually run in large scale and well established industry with a long track record compared to new or lessknown companies in private IPOs.

Secondly, the preparation of privatization program has been strictly set under the ministry of state owned enterprises agency in Indonesia at the first place. The ministry of state-owned enterprises or state-owned enterprises agency in Indonesia was a new development to bear responsibility in the supervision and development of SOEs. The legal proponent of SOEs itself holds ministerial position and supported by members of the House of Representatives through the legislation issuance (Law of SOEs No. 19/2003) on June 19, 2003. Moreover, the standardize legislation associated with the action of Privatization SOEs is also ratified in the Government Decree No. 33/2005, in which contained the regulation of all privatized SOEs should be competitive in its industry (Chapter 3, article 7 of Government Decree No. 33/2005). The cost of privatization itself must serve principles of fairness, transparency and accountability, which is set by the Minister of SOE (Chapter 4, part4, article 19 of Government Decree No. 33/2005).

Thirdly, the prominence state-owned enterprise is able to diminish the intervention of underwriter reputation, as government enterprise does not seek any advantage from the underwriter reputation. Thus, the purpose of underwriter within the privatization IPO is merely administers the public issuance and distribution of securities to the investors. Moreover, the legal regulation also emphasizes and holds the control over the tight screening over the appropriate underwriter for the privatization occurrences (Chapter 4, part 3, article 13-17of Government Decree No. 33/2005).

Lastly, the primary aim of privatization process itself is also influencing the degree of underpricing throughout the IPO. Thus, the government needs to finance the budget deficit by using the fund raised from the privatization of IPO and this underlying reason in some way will facilitate to diminish the degree of underpricing. 
However, all of the supportive evidence from the univariate test does not totally applicable for the multivariate analysis, which is conducted by using multiple regression analysis. The result of multiple regression analysis was in contrary with the univariate test as the outcome has proven that the nature of SOE does not exactly experience lower underpricing compared to the Non-SOE. This shows that the result of underpricing among SOE and Non-SOE to be similar one to another. The finding can be interpreted as the anomaly of underpricing is generally the same for both SOE and Non-SOE within the business society in Indonesia within the last 10 years period.

\section{Recommendation}

Based on the findings of the research, the author would like to address some useful recommendations, as follows:

- The findings from the research can give contributions for the future management of the companies which plan to carry out the IPO process. Management team will be more vigilant in doing the appraisal for the underpricing level, since lower underpricing is perceived to be better as it bear lower risk of the company. Thus, potential companies which will go public should be the one with the well-established with advance performance, which will inherent lower risk on the first place, just like the SOEs in this study.

- SOEs in this study are dominant firms in their respective industries and proven to have less underpricing during IPO. Meanwhile, other smaller companies which also have intention to go public should prepare their company's performance to be able to compete with the large scale companies in the market. To compensate for size disadvantage, smaller company should exhibit a high performance company, otherwise steep underpricing or failure in IPO may result. 


\section{REFERENCES}

Abeng, T. (2001). Indonesia, Inc: privatising state-owned enterprises. California: Times Academic.

Aktan, C. C. (1995). An Introduction to the theory privatization. The Journal of Social, Political, and Economic Studies , 20(2), 187215.

Alexakis, P. (2007). Are Share Issue Privatisations Fairly Priced? European Journal of Economis, Finance and Administrative Sciences, 60-68.

Allen, F., \& Faulhaber, G. R. (1989). Signaling by underpricing in the IPO market. Journal of Financial Economics , 23(2), 303-323.

Arthurs, J. D., Hoskisson, R. E., Busenitz, L. W., \& Jhonson, R. A. (2008). Managerial agents watching other Agents: Multiple agency conflicts regarding underpricing in IPO firms. Academy of Management Journal, 51(2), 277-294.

Astami, E. W., Tower, G., Rusmin, R., \& Neilson, J. (2010). The effect of privatisation on performance of state-owned-enterprises in Indonesia. Asian Review of Accounting, 18 (1), 5-19.

Aussenegg, W. (2000). Privatization versus Private Sector Initial Public Offerings in Poland. Multinational Finance Journal, 4(1-2), 6999.

Baker, H. K., \& Powell, G. (2005). Understanding Financial Management: A Practical Guide. Malden: Blackwell Publishing Ltd.

Barber, B. M., \& Lyon, J. D. (1996). Detecting abnormal operating performance: the empirical power and specification of test statistics. Journal of Financial Economics , 41(3), 359-399. 
Baron, D. P. (1982). A Model of the Demand for Investment Banking Advising and Distribution Services for New Issues. The Journal of Finance, 37(4), 955-976.

Bauwhede, H. V. (2009). On the relation between corporate governance compliance and operating performance. Accounting and Business ResearcH, 39(5), 497-513.

Beatty, R. P. (1989). Auditor Reputation and the Pricing of Initial Public Offerings. The Accounting Review, 64(4), 693-709.

Beatty, R. P., \& Ritter, J. R. (1986). Investment banking, reputation, and the underpricing of initial public offerings. Journal of Financial Economics, 15(1-2), 213-232.

Bel, G. (2002). Privatization: public offerings and political objectives. Applied Economics, 34(11), 1421-1432.

Boardman, A. E., \& Vining, A. R. (1989). Ownership and Performance in Competitive Environments: A Comparison of the Performance of Private, Mixed, and State-Owned Enterprises. Journal of Law \& Economics, 32, 1-33.

Carter, R., Dark, F., \& Singh, A. (1998). Underwriter reputation, initial returns, and the long-run performance of IPO stocks. Journal of Finance, 53, 285-311.

Chang, X., Gygax, A. F., Oon, E., \& Zhang, H. F. (2008). Audit quality, auditor compensation and initial public offering underpricing. Accounting and Finance , 48(3), 391-416.

Choi, S. D., \& Nam, S. K. (1998). The Short-Run Performance of IPOs of Privately- and Publicly-Owned Firms: International Evidence. Multinational Finance Journal , 2(3), 225-244.

Chowdhry, B., \& Sherman, A. (1996). The winner's curse and international methods of allocating initial public offerings. Pacific-Basin Finance Journal , 4(1), 15-30. 
Core, J. E., Guay, W. R., \& Rusticus, T. (2006). Does weak governance cause weak stock returns? An examination of firm operating performance and investors' expectations. Journal of Finance, 61(2), 655-687.

Desyetti, D., Adrianto, F., \& Rivai, D. (2004). Analisis fenomena underpricing di pasar modal Indonesia. Project Report. Lembaga Penelitian Universitas Andalas .

Dewenter, K. L., \& Malatesta, P. H. (1997). Public Offerings of StateOwned and Privately-Owned Enterprises: An International Comparison. The Journal of Finance, 52(4), 1659-1679.

Downes, J., \& Goodman, J. E. (2003). Barron's Finance \& Investment Handbook ( $6^{\text {th }}$ ed.). Hauppauge: Barron's Educational Series, Inc.

Dunbar, C. (2000). Factors affecting investment bank initial public offering market share. Journal of Financial Economics, 55, 341.

Ernyan, \& Husnan, S. (2002). Perbandingan Underpricing Penerbitan Saham Perdana Perusahaan Keuangan dan Non Keuangan di Pasar Modal Indonesia: Pengujian Hipotesis Asimetri Informasi. Jurnal Ekonomi dan bisnis Indonesia, 17.

Fama, E. (1980). Agency problems and the theory of the firm. Journal of Political Economy, 288-307.

Gan, J. (2009). Privatization in China : Experiences and Lessons. In J. R. Barth, J. A. Tatom, \& G. Yago, China's Emerging Financial Markets: Challenges and Opportunities. New York: Springer.

Geddes, R. (2003). IPOs and Equity Offerings. Burlington: ButterworthHeinemann. 
Ghozali, I., \& Mansyur, M. a. (2002). Analisis Faktor-Faktor yang Mempengaruhi Tingkat Underpricing Di Bursa Efek Jakarta. Jurnal Bisnis dan Akuntansi , 4.

Grinblatt, M., \& Huang, C. Y. (1989). Signalling and the Pricing of New Issues. The Journal of Finance , 44 (2), 393-420.

Hardiningsih, P., Suryanto, L., \& Chariri, A. (2002). Pengaruh Faktor Fundamental dan Resiko Ekonomi terhadap Return Saham pada Perusahaan di bursa Efek Jakarta. Jurnal Strategi dan Bisnis , 8.

Haskel, J., \& Szymansky, S. (1994). Privatization and the Labour Market : Facts, Theory, and Evidence. In M. Bishop, J. Kay, \& C. P. Mayer, Privatization and economic performance. New York: Oxford University Press, Inc.

Hill, H. (2000). The Indonesian Economy (2 ed.). Cambridge: Cambridge University Press.

Huang, Q., \& Levich, R. M. (1999). Underpricing of new equity offerings by privatized firms: An international Test. International Journal of Theoretical and Applied Finance , 6 (1), 1-30.

Ibbotson, R. G. (1975). Price performance of common stock new issues. Journal of Financial Economics , 2 (3), 235-272.

Ibbotson, R., Sindelar, J., \& Ritter, J. (1988). Initial public offerings. Journal of Applied Corporate Finance , 1, 37-45.

Irianto, G. (2004). A critical enquiry into privatization of state-owned enterprise: the case of PT Semen Gresik (Persero) TBK. Indonesia. University of Wollongong Thesis Collection .

Jain, B., \& Kini, O. (1999a). The life cycle of initial public offering firms. Journal of Business Finance and Accounting , 26, 12811307. 
Jensen, M., \& Meckling, W. (1976). Theory of the firm: Managerial behavior, agency cost, and ownership structure. Journal of Financial Economics , 3, 305-360.

Jones, S. L., Megginson, W. L., Nash, R. C., \& Netter, J. M. (1999). Share issue privatizations as financial means to political and economic ends. Journal of Financial Economics , 53 (2), 217253.

Larcker, D., Richardson, S. A., \& Tuna, I. (2005). Ratings add fire to the governance debate. Financial Times Mastering Corporate Governance Part Two.

Lieberman, I. W., \& Rahuja, S. (1995). An overview of Privatization in Russia. In I. W. Lieberman, J. Nellis, E. Karlova, J. Mukherjee, \& S. Rahuja, Russia: creating private enterprises and efficient markets. Washington: World Bank Publications.

Ljungqvist, A. (2006). IPO Underpricing. working paper, NYU, Stern School of Business .

Ljungqvist, A. P., Jenkinson, T., \& Wilhelm, W. J. (2000). Has the introduction of bookbuilding increased the efficiency of international IPOs? working paper, NYU, Stern School of Business .

Loughran, T., Ritter, J. R., \& Rydqvist, K. (1994). Initial public offerings: International insights. Pacific Basin Finance Journal , $2(2-3), 165-199$.

Megawati, W. (2010). Krakatau Steel faces probe over alleged IPO 'irregularities'. Metal Bulletin Daily, 240, 292-292.

Muscarella, C. J., \& Vetsuypens, M. R. (1987). A simple test of Baron's model of IPO underpricing. Journal of Financial Economics , 24 (1), 125-135. 
Netter, J. M., \& Megginson, W. L. (2001). From State to Market: A Survey of Empirical Studies on Privatization. Journal of Economic Literature , 39 (2), 321-389.

Perotti, E. C. (1995). Credible Privatization. The American Economic Review , 85 (4), 847-859.

Ramamurti, R. (1992). Why are developing countries privatizing? Journal of International Business Studies , 23 (2), 225-249.

Ritter, J. R. (1998). Initial Public Offerings. Contemporary Finance Digest , 2, 5-30.

Ritter, J. (1984). The hot issue market of 1980. Journal of Business , 57, 215-240.

Ritter, J. (1991). The long-run performance of initial public offerings. Journal of Finance , 46, 3-27.

Rock, K. (1986). Why new issues are underpriced. Journal of Financial Economics , 15 (1-2), 187-212.

Rodoni, A. (2002). Penawaran Saham Perdana: Pengalaman di Bursa Efek Jakarta 1990 - 1998. Simposium Nasional Keuangan, In Memoriam Prof. Bambang Riyanto , 17 (4).

Rondinelli, D. A. (1995). Privatization and economic transformation : the management challenge. In J. Prokopenko, Management for privatization: Lessons from industry and public service. Geneva: International Labour Office.

Samarakoon, L. P. (2010). The Short-Run Underpricing of Initial Public Offerings in the Sri Lankan Stock Market. Journal of Multinational Finance Management , 20, 197-213.

Seidenstat, P. (1999). Theory and Practice of Contracting Out in the United States. In P. Seidenstat, Contracting Out Government Services. Westport: Praeger Publishers. 
Sekaran, U. (2003). Research Methods for Business : A skill Building Approach. United States of America: John Wiley \& Sons, Inc.

Sherman, A. J. (2005). Preparing for an Initial Public Offering. In Raising Capital (2 ed., pp. 197-226). Broadway, NY: AMACOM.

Sikorski, D. (1989). The Perspective for Privatization in Singapore. Asian Journal of Public Administration , 11 (1), 74-91.

Welch, I. (1989). Seasoned Offerings, Imitation Costs, and the Underpricing of Initial Public Offerings. The Journal of Finance , 44 (2), 421-449. 